\title{
THE DINAMICS OF ACCESS ON TOURISM DEVELOPMENT IN LABUAN BAJO, INDONESIA
}

\author{
Abdul KODIR* \\ Universitas Negeri Malang, Faculty of Social Science, \\ Sociology Department, Indonesia, e-mail: abdul.kodir.fs@um.ac.id \\ Ardyanto TANJUNG \\ Universitas Negeri Malang, Faculty of Social Science, \\ Geography Department, Indonesia, e-mail: ardyanto.tanjung.fis@um.ac.id \\ I Komang ASTINA \\ Universitas Negeri Malang, Faculty of Social Science, \\ Geography Department, Indonesia, e-mail: komang.astina.fis@um.ac.id \\ Muhammad Afif NURWAN \\ Universitas Negeri Malang, Faculty of Social Science, \\ Sociology Department, Indonesia, e-mail: afifnurwan@gmail.com \\ Ahmad Gatra NUSANTARA \\ Universitas Negeri Malang, Faculty of Letter, \\ English Literature Department, Indonesia, e-mail: pgatranusantara11@gmail.com

\section{Risdawati AHMAD} \\ Universitas Negeri Malang, Faculty of Social Science, \\ Sociology Department, Indonesia, e-mail: risdawatiahmad@gmail.com
}

Citation: Kodir, A., Tanjung, A., Astina, I.K., Nurwan, M.A., Nusantara, A.G \& Ahmad, R. (2020). THE DINAMICS OF ACCESS ON TOURISM DEVELOPMENT IN LABUAN BAJO, INDONESIA. GeoJournal of Tourism and Geosites, 29(2), 662-671. https://doi.org/10.30892/gtg.29222-497

\begin{abstract}
Tourism is one of the sectors encouraged by the Indonesian government to increase economic growth. one of the efforts made is to establish Labuan Bajo as a national tourism strategic area. This study aims to explain the dynamics of access contested by some actors in tourism governance in Labuan Bajo. A qualitative approach was employed in this study. Data were gathered through interviews, focus group discussion, and document analysis. The results of this study indicate that tourism access is dominated by actors who have the power of capital and they control access to economic circles of the tourism management. On the other hand, societies are unable to involve as the main economic actors around the tourism governance.
\end{abstract}

Key words: Tourism, Development, Access, Labuan Bajo

\footnotetext{
* Corresponding author
} 


\section{INTRODUCTION}

Tourism is a strategic sector because it can contribute to economic growth, encourage and create jobs, investment development, and increase community income (Kim et al., 2016; Du et al., 2016). In addition, this sector spurs economic growth in a region (Cárdenas-García et al., 2015). In Indonesia , the tourism sector ranks $4^{\text {th }}$ after oil and gas, coal, palm oil in terms of national foreign exchange earnings (Ministry of Tourism, 2016). Consequently, the Indonesian government expects that by 2020 it can become a major source of foreign exchange to exceed 3 other commodities. An effort was carried out to project 10 priority destinations by making Bali a national tourism pilot. One of them is in the area of Labuan Bajo, West Manggarai Regency.

Deciding Labuan Bajo region as one of the national tourism priority destinations is because the region has a high tourist attraction both in the eyes of local and international tourists. Labuan Bajo is one of the gates of tourism in eastern Indonesia due to the presence of the Komodo National Park (Kodir, et al., 2019). At present, the region has four infrastructure development programs in accordance with Presidential Regulation No. 32 of 2018 concerning operational procedures in Labuan Bajo and Flores. The four programs include: 1) Mapping out Labuan Bajo Tourism Strategic Area; 2) Developing International Komodo Airport; 3) Installing 20 Mooring Buy Points within the Komodo National Park area; 4) Constructing Integrated Waste Management of Labuan Bajo.

So far, the contribution of the tourism industry in West Manggarai Regency is quite large towards the increase in Regional Original Revenue (PAD). PAD obtained in 2017 reached 125 billion rupiah. In addition, the regency also receives increased income at $4.76 \%$, compared to previous revenues which only amounted between $4.45 \%$ in 2015 and 4.08\% in 2014 (Padarnews.com, 2019). The increase is obtained through the number of tourist visits from ticketing and hotel taxes. In recent years, there has been an increase in the number of tourists and hotels in the region (Figure 1 and Figure 2).

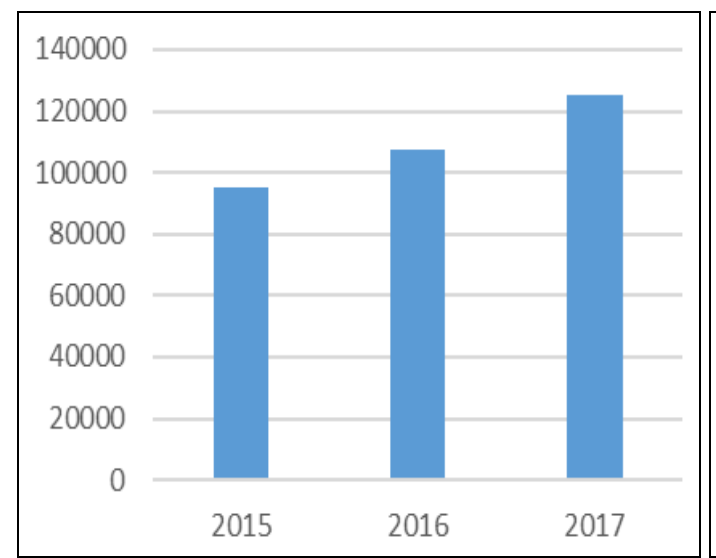

Figure 1. Number of tourists in West

Manggarai (Source: Badan Pusat Statistik, 2018)

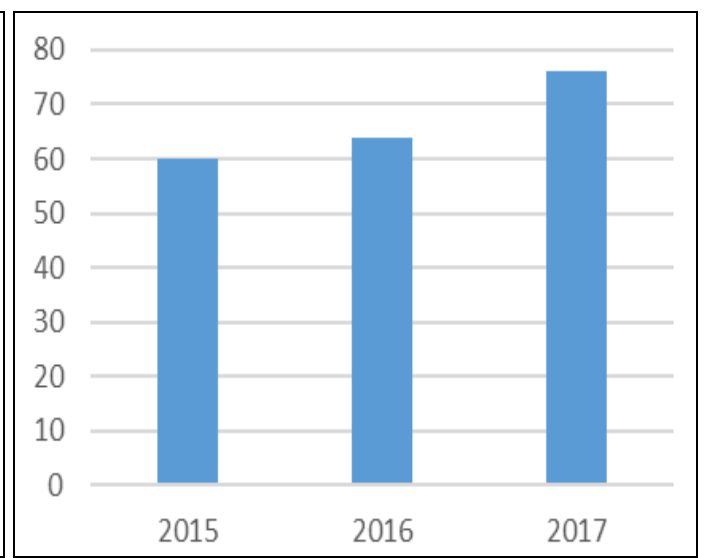

Figure 2. Number of Hotel Growth in West Manggarai (Source: Badan Pusat Statistik, 2018)

However, such conditions do not exclusively benefit local people from the development of tourism in West Manggarai. Wahyuti et al. (2015) argues that the benefits of tourism for local people are not well attained due to limited absorption of labor as a result of the low level of education and skills possessed by the communities. 


\section{LITERATURE REVIEW}

The beauty of nature, biodiversity and culture are an important capitals for Indonesian tourism. This capital is one of the keys that encourages international tourists to visit and enjoy tourism in Indonesia. One indicator to see positive trends about Indonesian tourism is the increasing number of tourists contributing to foreign exchange which reached 12 million billion dollars in 2016 (NESPARNAS, 2016).

The trajectory of Indonesian tourism development began in the 1960 (Hampton \& Jayacheya, 2015) and has experienced growth since the 1980s (Booth, 1990). With this increase, tourism studies in Indonesia have been carried out by both domestic and foreign researchers throughout Indonesia (Henderson, 2009; Fallon, 2011; Sutawa, 2012; Divinagracia et al, 2012; Cole 2012 \& 2017; Kurniawan et al, 2016; Towner, 2016; Wardani et al, 2017; Hampton \& Mahaden, 2017; Atmojo et al, 2017; Kodir, 2018; Kinseng et al, 2018; Kodir et al., 2019; Atmodjo et al., 2019; Darojat et al., 2020).

Studies on tourism and its development have been enacted in Labuan Bajo which documented several implications for the local people. First, Erb (2014) explained that Mega events such as Sail Komodo held in Labuan Bajo attracted many visitors but did not have a direct impact on increasing the income of the local people.

Second, Wahyuti et. al (2015) also added that local communities did not fully benefit from tourism activities due to their low education level to be hired. Lastly, the local government has spent funds reaching 30 billion for tourism needs. However, people in Labuan Bajo area experienced a water crisis because only 24 percent of the houses were flowed by the local water company (PDAM). Based on the aforementioned complexities above, this present study investigates tourism policies enacted in Labuan bajo, Indonesia through a framework of Access by Ribot and Paluso (2009).

\section{METHOD AND RESEARCH SITE}

This research was conducted on 2 June 2019 until 27 July 2019. A qualitative approach was employed in this study. The data data was gathered in two stages. First, conducting interviews with several related stakeholders such as Department of Tourism; Investment and Licensing Office, Komodo National Park Manager, Tourism Entrepreneurs (Hotels, Resorts, Diving \& Snorkeling), West Manggarai DPRD, Local Operators, Tourism Authority Agencies, Fishermen Groups, Sunspirit - NGO, and Local Communities. Second, collecting data through focus group dicussion. In addition, Observations were conducted in tourism activities. To gain deeper analysis, secondary data gathering was also done through document analysis from the Badan Pusat Statistik in West Manggarai Regency, Tourism Business Map, Map of Determination of BOP Labuan Bajo, Map of Supporting Infrastructure Development, Legislation and Other Supporting Documents.

Analysis of the data of this study uses thematic analysis. Where the thematic analysis is carried out on the results of the interview (Bryman, 2016). There are several stages carried out from the thematic process of analysis. First, do the transcript of the results of the interview. After that, coding the results of interview transcripts from several parisipers, grouping the results of interviews according to the theme of the discussion. And the last is to interpret the findings from the predetermined themes (Bryman, 2016).

\section{RESULT AND DISCUSSION}

\section{The context of tourism development in Labuan Bajo}

The history and development of tourism in Labuan Bajo, cannot be separated from the presence of the Komodo National Park (TNK) (Widaningrum \& Damanik, 2016). On March 6, 1980, the government designated the area between Sumbawa Island and Flores 
Island as Komodo National Park. KNP, with an area of 173.300 ha, covering Komodo Island, Rinca Island, Padar Island, Nusa Kode, Gili Motang, and surrounding small islands. The beauty of the tourist nature and the presence of endangered species of Komodo (Varanus Komodensis) have served as intriguing attractions that lure tourists to visit. The designation of Komodo dragons as the Land of Humans and Biosefer by UNESCO in 1977, followed by their designation as World Natural Heritage in 1991, had a significant impact on the development of tourism, including in Labuan Bajo.

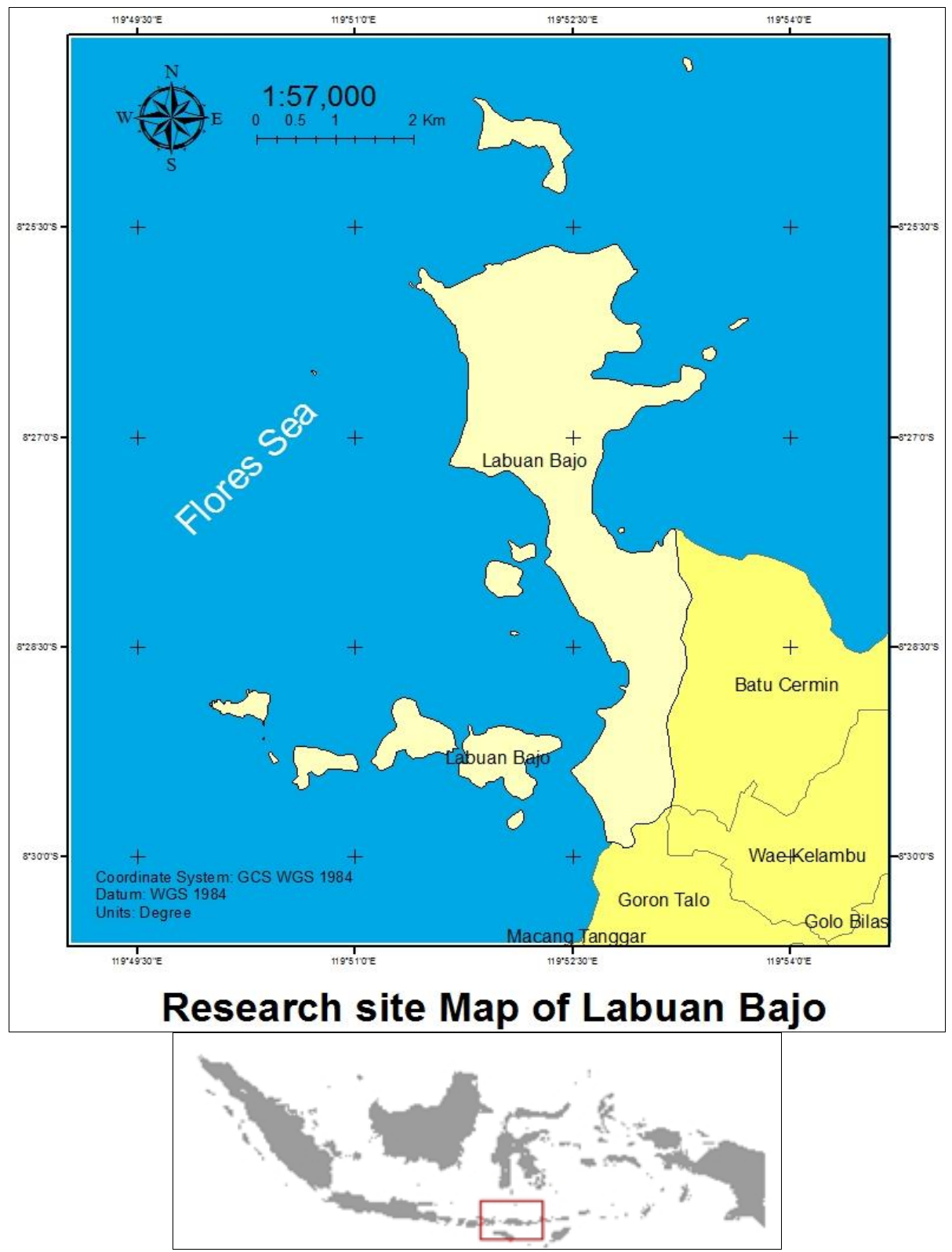

Figure 3. Research Site Maps 
This can be seen from the number of tourist visits in the 1980-1990 period which reached 20-40 thousand tourists per year (Afioma, 2016). In the era of decentralization where marine tourism, landscapes, and cultural attractions are also the focus of development - the tourism sector is increasing. The development of tourism in West Manggarai began when the Provincial Government of East Nusa Tenggara (NTT) established Labuan Bajo as one of the NTT provincial tourism destinations in 1996.

From 1995 to 1997 there were around 26 thousand foreign tourists visiting the Manggarai district, which most of them visited to see the charm of the giant lizard tour, Komodo (Haryanto, 2018). Additionally, Labuan Bajo is the main entrance to the island of Flores (Damanik, 2016). The mining sector also had served as one of the economic boosters of the Manggarai area, especially in Labuan Bajo. However, the irony of mining led to protests everywhere including in Labuan Bajo in 2008, so tourism was then seen as the only good and appropriate sector (Afioma, 2016).)

Tourism development and its supporters also continue to be improved, do not miss the promotions carried out to invite tourists to visit. In $2011 \mathrm{KNP}$ was chosen as one of the finalists of the New Seven Wonders of Nature. Even though the government finally withdrew KNP from the event, it cannot be denied that KNP's prestige as the home of the Komodo dragon species has skyrocketed. Promotional activities continue to be improved, one of them is through the Sail Komodo event in 2013 and the Tour de Flores event with a budget of 3.7 trillion and 32 billion rupiah, respectively. However, the concern that arises subjects to corruption cases (Erb, 2015).

In the development sector, Labuan Bajo continues to enhance the development of supporting infrastructure for tourism such as airports, ports and highways. In addition, in 2013, East Nusa Tenggara was designated as a tourism support region in the Master Plan for the Acceleration of Development and Expansion of Indonesia's Economic Development (MP3EI) 2011-2025, one of them thanks to the rapid development of KNP and Labuan Bajo tourism. Then in the same year, the INFEST (Flores Ecotourism Development Innovation for Sustainable Trade) program was held in a number of villages and cities in Flores, one of which was held in Labuan Bajo.

The great potential of Labuan Bajo also received more attention from the Central Government when in 2016 it was chosen to be one of the "10 priority tourism destinations", followed by the establishment of the Tourism Authority Agency by the central government in 2018, as an effort to accelerate tourism development in Labuan Bajo. The capital of West Manggarai is considered as the entrance to access tourism areas, both in KNP or tourism destinations in NTT, so it needs to be continuously optimized. Currently, the development of tourism in Labuan Bajo along with its supporting facilities is quite rapid. Exclusive resorts, star hotels, and entertainment venues are widely available. Tourist ships and cruise ships also leaning around the waters of Labuan Bajo. In addition to the tourist attraction of the KNP region, tourist attractions in Labuan Bajo, which until now continue to be developed, such as Puncak Waringin, Angel Island, Batu Cermin Cave, Verhoven Stacking Stone, Tanjung Rangko, Toro Sitangga, Ular Island, Bird Island, Kelumpang, Menjerite Beach, Pramuka Peak, Komodo Warloka, Pasir Putih, Tanjung Boleng, Watu Wangkung, Pontianak, Golo Mori and M. Tanggar, are also choices for tourists (Haryanto, 2018).

\section{Access to Tourism Development in Labuan Bajo}

Access is an ability to take advantage of something that depends a lot on the constellation of power (Ribot \& Peluso, 2009). Including attracting a profit from tourism sources. Access is a relevant analysis in explaining the relations of the interests of actors fighting over-tourism management, especially in Labuan Bajo, Indonesia. Labuan Bajo is 
the locus in developing access analysis because tourism development in the region is quite significant. Labuan Bajo is the main entrance before tourists will go to the Komodo National Park. Through access theory developed by Ribot and Peluso (2009), the authors aim to identify and critically review access to tourism development in Labuan Bajo. By focusing on natural resources, which are also sources of tourism, the author wants to do then do an in-depth exploration of power. Power becomes one part of the mechanism, process, and relationships that are closely related to a bundle of power and a web of power that forms access resources are no exception to tourism sources.

In the context of this study, some people and institutions with pretensions have considerable possibilities in controlling tourism resources with the power relations they have (Bowen et al., 2017; Saito \& Ruhanen, 2017). But on the other hand, some of these people or institutions maintain their access through who controls the resources. In addition, an analysis of access also helps in understanding why some people or institutions benefit from resources in the presence or absence of ownership of goods in them. From the results of this study, the writer has identified several actors and their interests in accessing tourism development in Labuan Bajo.

Local Government, Investors, and Tourism Authority Agencies (BOP): Strengthening the relationship between a bundle of powers and a web of powers

The number of tourists visiting Labuan Bajo every year shows a positive trend. Consequently, tourists need adequate accommodation facilities for the convenience of their trip. Therefore, development is necessary to support tourism needs. In addition, local governments consider the people of Labuan Bajo to be unable to adapt to changes in tourism. In addition, they also have capital constraints in developing business in the field of tourism. With this gap, investors are given as much opportunity as possible to invest their capital, and at the same time can easily obtain tourism management permits and their territory. Because after all, investment is an inseparable part of tourism development (Banarjee, et al., 2016; Li et al., 2017; Sokhanvar, 2019). This is inseparable from the target of the central government that wants to boost the number of tourists and foreign exchange earnings from the tourism sector in Labuan Bajo, which is as many as 500,000 visits in 2019 and 20 trillion rupiahs of foreign exchange.

There are several actors involved in tourism management such as local governments, entrepreneurs, BOP, and local communities. Some of these actors have different interests. Some of these actors have the advantage of access to control and access to rule except the local community. Access to control is the ability to mediate other accesses. Control leads to the examination and supervision of actions, functions, or forces that supervise and regulate free action whereas access control requires power to maintain some access resources openly. In practice, access control can be realized through its institutions and apparatus while access to rules works through regulations and laws. Through clear regulations and laws, investors or business people feel safe to invest their capital through the development of the tourism industry.

Meanwhile, the influx of large investments provides benefits for the regional government or the Tourism Authority Agency (BOP) to increase the number of tourists which will directly have an impact on increasing the country's foreign exchange and local revenue. Institutions and regulations are important drivers for the actors to achieve their interests. Because basically between access to control and access to the rule are two complementary things. Both of these, have an important role in efforts to formulate relations between actors in the relationship to resources, management, and 
Abdul KODIR, Ardyanto TANJUNG, I Komang ASTINA, Muhammad Afif NURWAN, Ahmad Gatra NUSANTARA, Risdawati AHMAD

use of tourism resources. The emergence of regulations and apparatus that are accommodating to the tourism industry, of course, is not something that has suddenly arisen. However, because in access, there are a variety of bundles and webs of powers that make these actors able to benefit from the management of tourism.

The power relation runs on the carrying capacity of politicians who then have networks with business people and investors. The relationship between local government, political elites, and business people is unavoidable. Business/investor needs are looking for maximum profits in the West Manggarai area through various types of businesses that they run, especially in the tourism sector. Wahyuti (2013) explained that the money circulating in the Labuan Bajo area was 838 billion rupiahs. However, most of that amount of money was received by tourism operators and ship entrepreneurs, most of whom were foreigners with a percentage of $75.55 \%$.

The Komodo National Park and the Regional Government received $2.09 \%$. Hotels, restaurants, retail/souvenir shops get $22.36 \%$. While on the other hand, local governments are trying to bring in funds for development. In the midst of the limitations of the Regional Revenue Budget (APBD) in developing underdeveloped areas in West Manggarai), local governments often aim at projects that come down from the center as wetlands hunting for profits made through corrupt budget absorption, and buying and selling political permits (consensus, operating permits, and land concessions) (Erb, 2015). Therefore, if there are projects that come from the center, they always receive and are very well facilitated.

Another actor who has a big interest in tourism management is the Tourism Authority Agency (BOP). The BOP is an independent and non-ministerial body formed directly by the President through Presidential Regulation number 32 of 2018. BOP has the task of accelerating the development process in tourism with a principle of developing sustainable and sustainable ecotourism, supporting the establishment of a single destination single management system in the effort to manage tourism in the regions, encourage investment rates, and organize major promotions to introduce tourism destinations and try to attract tourists to travel to Indonesia.

In the context of tourism in Labuan Bajo, BOP has two different sides. On the first hand, BOP is very useful in advancing regional development through its authority that can carry out and control the activities of development permits (investment), make policies and synchronize policies with local governments where the role according to the people in local government is very helpful because if implementation development only relies on APBD funds so it will not be able to run quickly. That is because the funding owned by BOP comes from APBN funds worth 16 Trillion rupiahs, non-binding donation funds, and cooperation with local developers. However, on the other hand, BOP can be a threat. Since the existence of BOP is under the President and the Agency has authority, this is awfully disturbing in the implementation of development at the regional level, each of which is carried out through the Regional Autonomy Law. One case that occurred was when the Sail Komodo event was held in 2013, a budget that reached 3.7 Trillion rupiahs disbursed from the center does not have a significant impact on people's lives, and the involvement of local governments is also completely invisible.

In addition, BOP will also be given full rights in the management of sea and land areas. With its authority, BOP has the right to rearrange the spatial plan and apply to zone to coastal areas and small islands, including granting management rights to third parties to obtain rental results. Thus, through a set of regulations and institutions, these actors gain legal access to tourism resources even though at first, they did not have any basis for rights. Whereas at the time, the interests of the local community did not get a place in 
tourism management. Tourism is only centralized by local governments and legal entities without presenting the role of local communities (Yankholmes, 2018).

\section{Position of Local Communities Interest among the Interests of Tourism Investment}

From the results of the field research, at least the researchers dug up information relating to the interests and needs of the local community in dealing with the big wave of the tourism industry in Labuan Bajo. First, local people who live in coastal areas need a boat/fast engine to become a mode of transportation in the waters, both for the needs of fishing in the ocean and tourist boats owned by the community.

Second, the people of Labuan Bajo need adequate access to capital and are not loan sharks for them to buy production/capital needs for their businesses whether they are already running or will be running. Because so far many people have relied on pawnshops and private lenders who can be said to charge huge interest for people who pawned their goods or borrowed some money for capital.

And lastly, they have an interest so that the government immediately issues regulations/laws that can protect their interests in; tourism participation as manager, protection, and distribution of community work goods such as rice/garden harvests, fish/livestock, handicraft items, cultural products (clothing and accessories), and protection of ownership of customary lands from investors. Which will be purchased to be rebuilt into a resort, hotel, restaurant or other building. However, until now, the interests of the community have not been accommodated by the local government.

In short, they only become a complement to the tourism sector. This is due to their limitations on market access and capital access (Ribot \& Peluso, 2009). Not only that, their lack of knowledge of the important role of tourism in development (Sihombing et al., 2017). In addition, in the coastal areas, most of them left their livelihoods as fishers and turned into guides, Shipmen (ABK), chef. The involvement was not of their choice because they were aware but rather the pressure of the tourism industry.

\section{CONCLUSION}

The development of tourism in the tourism sector in Indonesia is essentially needed, especially to unfold reliance on state revenues such as coal, gas oil, and palm oil, which have the risk of environmental damage. The results of this study indicate that the tourism sector in Labuan Bajo still needs to be developed, considering the target provided by the government is quite high for tourists. For this reason, several actors are needed in managing tourism. However, there are management gaps in tourism access. Access to tourism management has been dominated by actors with large capital strengths such as investors, local governments, and BOP. Whereas the community has limited access to tourism because of its limitations on access to capital.

The local community is only a compliment does not have a significant role in the development of tourism in Labuan Bajo.This research is only limited to the identification and interests of the actors involved in accessing tourism management. It is hoped that in future studies, other researchers can explain related strategies of local communities in tourism management involvement even with limited access.

In addition, by considering the problems that arise from the development of tourism, researchers provide recommendations for the parties involved to do the following things: first, the central and regional governments to discuss the limits of government power, especially in the realm of tourism development in Labuan Bajo. This negotiation must also involve the local community as the 'host' and the investor's 
representative as the party needed to encourage development activities in the Labuan Bajo area. The purpose of this negotiation is to accommodate and voice all aspirations and needs of the community and tourism management actors directly.

This negotiation is expected to produce fair regulations from problems that have existed or have not yet been resolved, such as the unclear authority of regional and central government in tourism management, privatization of tourism resources, community limitations on clean water, and land liberation. Second, the community to form community based forums based on region and profession that will be very useful for them in building people's power and bargaining power, as a communication forum for internal / external communities in a particular area, as a forum in which they discuss development developments, oversee and criticize the government, and determination of attitude.

\section{REFERENCES}

Afioma, G. (2016). Pencaplokan dan Ketidakadilan Pariwisata. Retrived from http://arc.or.id/wpcontent/uploads/2017/02/Pariwisata-pembangunan-dan-Keadilan-Agraria-di-Flores-Seri-Pertama-2016.pdf.

Atmodjo, E., Lamers, M. \& Mol., A. (2019). Governing Dynamics in Marine Conservation Tourism in Raj Ampat, Indonesia. Tourism Planning \& Development, vol. 16, no. 5,p. 1-19.

Banerjee, O., Cicowiez, M. \& Cotta, J. (2016). Economics of tourism investment in data scarce countries. Annals of Tourism Research, vol. 6o, p. 115-138.

Booth, A. (1990). The tourism boom in Indonesia. Bulletin of Indonesia Economic Studies, vol. 9, no. 3, p. $331-358$.

Bowen, D., Zubair, S. \& Altinay, L. (2017). Politics and Tourism Destination Development: The Evolution of Power, Journal of Travel Research, vol. 56, no.6, pp. 725-743.

Bryman, A. (2016). Social Research Methods. 5th ed. Oxford: Oxford University Press Inc.

Cárdenas-García, P. J., Sánchez-Rivero, M. \& Pulido-Fernández, I. J. (2015). Does Tourism Growth Influence Economic Development?. Journal of Travel Research, vol. 54, no. 2, p. 206-21.

Cole, S. (2012). A political ecology of water equity and tourism: A Case Study From Bali. Annals of Tourism Research, vol. 39, no. 2, p. 1221-1241.

Cole, S. (2017). Water worries: An intersectional feminist political ecology of tourism and water in Labuan Bajo, Indonesia. Annals of Tourism Research, vol. 67, p. 14-24.

Damanik, J. (2015). Lack of Stakeholders Partnership in Destination Management: Lesson Learned from Labuan Bajo, Eastern Indonesia. Asian Journal of Tourism Research, vol. 1, no. 2, p. 165-189.

Darojat, K., Kurniawan, N. \& Retnaningdyah, C. (2020). Evaluation of Water Quality Based on Macrozoobenthos as a Bioindicator in the Four Springs of Wana Wiyata Widya Karya Tourism Area, Cowek Village, Purwodadi District, Pasuruan Regency. Journal of Indonesian Tourism and Development Studies, vol. 8, no. 1, p. 1-8.

Divinagracia, A.L., Divinigarcia., G.R.M. \& Divinigarcia, G.D. (2012). Digital Media-Induced Tourism: The Case of Naturebased Tourism (NBT) at East Java, Indonesia. Procedia - Social and Behavioral Sciences. vol. 57, p. 85 - 94.

Du, D., Lew, A.A. \& Ng, P.T. (2016). Tourism and Economic Growth. Journal of Travel Research, vol. 55, no. 4, p. 454-64.

Erb, M. (2015). Sailing to Komodo: Contradictions of tourism and development in eastern Indonesia. ASEAS Austrian Journal of South-East Asian Studies, vol. 8, no. 2, p. 143-164.

Fallon, F. (2001). Conflict, power and tourism in Lombok. Current Issues in Tourism, vol. 4, no. 6, pp. $182-194$.

Handerson, J. (2009). Transport and tourism destination development: An Indonesia perspective. Tourism and Hospitality Research, voll. 9, p. 199-208.

Hampton, M.P. \& Jayacheya, J. (2015). Power, ownership, and tourism in small island: Evidence from Indonesia. World Development, vol. 54, p. 172-189.

Haryanto, V. (2018). Jejak neoliberal dalam pembangunan pariwisata. Retrived from https://sunspirit for justiceandpeace.org/2018/o3/o2/jejak-neoliberal-dalam-pembangunan-pariwisata-di-manggarai barat-flores/.

Kemenpar. (2016). Accountability Report of Tourism Ministry Performance in 2015. Jakarta (ID): Kemenpar-RI.

Kinseng, R.A., Nasdian, F.T., Fatchiya, A., Mahmud, A. \& Stanford, R.J. (2018). Marine-tourism development on a small island in Indonesia: blessing or curse?. Asia Pacific Journal of Tourism Research, X(X),1-12.

Kim, N., Song, H. \& Pyun, J.H. (2016). The Relationship among Tourism, Poverty, and Economic Development in Developing Countries: A Panel Data Regression Analysis. Tourism Economics, vol. 22, no. 6, p. 1174-90. 
Kodir, A. (2018). Tourism and development: land acquisition, achievement of investment and cultural change (case study tourism industri development in Batu city, Indonesia). Geo Journal Tourism and Geosites, vol. 21, no. 1, p. 253-265.

Kodir, A., Tanjung, A., Sumarmi, Ahmad, R. \& Simanjuntak, T.B. (2019). Tourism Governance In Komodo National Park, Indonesia: Blessing Or Curse?. GeoJournal of Tourism and Geosites, vol. 27, no. 4, p. 1663-1667.

Kurniawan, F., Adrianto, L., Bengen, D.G. \& Prasad, L.B. (2016). Vulnerability assessment of small island to tourism: The case of the marine tourism Matra Park of the Gilis Islands, Indonesia. Global ecology and conservation, vol. 6, p. 308-326.

Li, X., Huang, S.S. \& Song, C. (2017). China's outward foreign direct investment in tourism. Tourism Management, vol. 59, p. 1-6.

Mahadevan, R., Amir, H. \& Nugroho, A. (2017). Regional impacts of tourism-led growth on poverty and income: Inequality: A dynamic general equilibrium analysis for Indonesia. Tourism Economics, vol. 23, no. 3, p. 614-631.

Padarnews.com. (2019). Pembangunan infrastruktur pariwisata kerek PAD Mabar naik jadi RP 135 Miliar. Retrived from http://www.padarnews.com/2019/o7/12/pembangunan-infrastruktur-pariwisata-kerekpad-mabar-naik-jadi-rp135-miliar/.

Ribot, J.C \& Peluso, N. (2009). A Theory of Access. Rural Sociology. vol. 68, no. 2, p. 153-181.

Saito, H. \& Ruhanen, L. (2017). Power in touris stakeholders collaborations: Power types and power holders. Journal of Hospitality and Tourism Management, vol. 31, p. 189-196

Sihombing, A., Gunawijaya, J. \& Akbar, G.N.P. (2017). Local Tourism Awareness and Knowledge: Community Views in Wanayasa, e-Review of Tourism Research (eRTR), vol. 14, no. 5/6, p. 188 - 123.

Sokhanvar, A. (2019). Does foreign direct investment accelerate tourism and economic growth within Europe? Tourism Management Perspectives, vol. 29, p. 86-96.

Sutawa, K.G. (2012). Issues on Bali Tourism Development and Community Empowerment to Support Sustainable Tourism Development. Procedia Economics and Finance, vol. 4, p. 413 - 422.

Towner, N. (2016). How to manage the perfect wave: Surf Tourism management in the Mentawai Islands, Indonesia. Ocean and Coastal Management, vol. 119, p. 217-226.

Wardani, M.P., Fahrudin, A. \& Yulianda, F. (2017). Analysis of succesfull strategy to develop sustainable marine ecotourism in Gili Bawean Island, Gresik, East Java, IOP Conference Series. Earth and environmental Science, vol. 89, p. 12-36.

Wahyuti, E., Wibowo, T., Iriyono, S., Syari'fudin, I., Kurniawan, M., Adnan, A., Indriasari, D., Buaihi, D. \& Priska, M. (2013). Kajian Peranan Taman Nasional Komodo dalam perekonomian Kabupaten Manggarai Barat Propinsi Nusa Tenggara Timur (Studi Kasus Pengembangan Aspek Pemanfaatan Ekowisata). Labuan Bajo: Balai Taman Nasional Komodo.

Widaningrum, A. \& Damanik, J. (2016). Improving Tourism Destination Governance: Case of Labuan Bajo City and the Komodo National Park, Indonesia, The Social Sciences, vol. 11, no. 21, p 5043-5051.

Wijaya, N. \& Furqan, A. (2018). Coastal Tourism and Climate-Related Disasters in and Archipelago Country of Indonesia: Tourists' Perspective. Procedia Engineering, vol. 212, p. 535-542.

Yankholmes, A. (2018). Tourism as an exercise in three-dimensional power: Evidence from Ghana. Tourism Management Perspectives, vol. 25, p. 1-12.

*** Badan Pusat Statistik. (2018). Kabupaten Manggarai Barat dalam Angka 2018. BPS Kabupaten Manggarai Barat.

*** NESPARNAS. (2016). Ministry of tourism in the central statistics agency (BPS). Balance of national tourism satellite (Nesparnas). Jakarta: Deputy of Institutional Development of Tourism.

Submitted:

26.01.2020
Revised:

24.04.2020
Accepted and published online 29.04.2020 